\title{
Hubungan Perilaku Kekerasan Ayah terhadap Temperamen Remaja
}

\author{
Sri Yuliani Putri1, Jumaini2, Erna Marni3 \\ Program Studi Ilmu Keperawatan Sekolah Tinggi Ilmu Kesehatan (STIKes) Hang Tuah, \\ Jl. Mustafa Sari No. 5 Tangkerang Selatan Pekanbaru, Riau - 28000. \\ E-mail: yputry@gmail.com
}

Diterima: 6 April 2019

Disetujui: Maret 2020

\begin{abstract}
Abstrak
Perilaku kekerasan ayah seperti membentak dan memberi hukuman fisik termasuk kedalam salah satu pola pengasuhan yang disebut otoriter. Pola asuh ialah salah satu faktor yang mempengaruhi temperamen. Temperamen merupakan perbedaan individu dalam respon perilaku atau karakteristikyang telah ada sejak lahir namun dapat berubah dan berkembang bersamaan dengan pengalaman yang dialami individu. Penelitian ini bertujuan untuk mengetahui hubungan perilaku kekerasan ayah terhadap temperamen remaja. Jenis penelitian ini adalah penelitian kuantitatif dengan metode korelasi menggunakan pendekatan cross sectional. Populasi pada penelitian ini sebanyak 596 orang. Jumlah sampel pada penelitian ini sebanyak 145 orang responden yang diambil menggunakan teknik Stratified Random Sampling dan simple random sampling. Alat ukur yang digunakan berupa kuesioner. Analisa yang digunakan adalah analisa bivariat dengan uji statistik chisquare. Hasil penelitian yang diperoleh adalah tidak terdapat hubungan yang signifikan antara perilaku kekerasan ayah dengan temperamen remaja dengan nilai $p$-value surgency $=1000$, $p$-value effortful control $=0,083$, $p$-value negative affectivity $=0,370$ dan $p$-value affiliativeness $=0,550>(\alpha$ 0,05). Dari hasil penelitian dapat disimpulkan bahwa perilaku kekerasan ayah tidak berpengaruh terhadap temperamen remaja hal ini dapat disebabkan adanya faktor lain yang lebih kuat dalam mempengaruhi temperamen remaja seperti lingkungan dan teman sebaya. Orang tua diharapkan dapat memberikan contoh perilaku yang baik pada remaja dengan tidak memperlihatkan kemarahan dan emosi yang berlebihan karena bagaimanapun lingkungan akan mempengaruhi sikap dan perilaku seorang remaja.
\end{abstract}

Kata Kunci: Perilaku Kekerasan Ayah, Remaja, Temperamen

Rujukan artikel penelitian:

Putri, S. Y., Jumaini., Marni, E. (2019). Hubungan Perilaku Kekerasan Ayah temperamen Remaja. Jurnal Ilmiah Keperawatan Indonesia. Vol. 3 (1): 42-56. 


\title{
The Relationship between Father's Violent Behavior towards Temperament of Teenager
}

\begin{abstract}
Father's violent behavior like yelling and physical punishment is included in one of the parenting patterns which is called authoritarian. Parenting is one of the factors that influence temperament. Temperament is an individual difference in behavioral or characteristics responses that have existed since birth, but can change and develop along with individual experience. This study aimed to determine the correlation of father's violent behavior to adolescents temperament. This research is quantitative research with a correlation method by using a cross sectional approach. The total population of this research was 596 people. The samples in this study consist of 145 respondents by using Stratified Random Sampling and simple random sampling techniques. The measuring instrument used a questionnaire. The analysis that used was bivariate analysis with chi-square statistical test. The results of this study showed that there was no significant correlation between father's violent behavior and adolescents temperament surgency p-value $=1000$, effortful control $p$-value 0,083, negative affectivity $p$-value 0,370 and affiliativeness 0,550 $>(\alpha 0,05)$. From the results of the study it can be concluded that father's violent behavior has no influence on the adolescents temperament, this can be due to other factors that more strongly influence the temperament of adolescents such as the environment and peers. Parents are expected to provide good examples in adolescents with didn't showing excessive anger and emotion because the environment will affect attitudes and behavior of a adolescents.
\end{abstract}

Keywords: Adolescents, Father's Violence Behavior, Temperament 


\section{PENDAHULUAN}

Remaja adalah salah satu tahap perkembangan hidup manusia ketika seseorang yang belum dewasa mencapai puncak pertumbuhan jasmani dan mental. Secara umum rata-rata masa remaja dimulai dari usia 12 sampai 18 tahun, pada masa sekolah menengah serta masa intelektual kedua (Fudyartanta, 2012). Masa remaja bukanlah perihal yang mudah dihadapi. Agar mengerti jiwa remaja dan juga mencari solusi yang sesuai untuk permasalahan yang ada, maka kita harus memahami tentang remaja dan juga perkembangan psikologinya, diantaranya pemahaman, kemampuan berpikir, emosi, seksual, interaksi dengan lingkungan, religi, kepribadian dan perilaku (Sarwono, 2012).

Perilaku adalah reaksi individu terhadap stimulus baik dari dalam maupun dari luar yang diproses lewat pengetahuan, pemahaman, perasaan, sikap, emosi, serta kemampuan individu dalam aktivitas fisik. Pembentukan perilaku menurut teori belajar, dapat berupa hasil interaksi individu dengan lingkungan. Pengalaman yang menyenangkan dapat menimbulkan perilaku positif, sebaliknya pengalaman yang tidak menyenangkan dapat menimbulkan perilaku negatif (Aisyah, 2015).

Penelitian yang dilakukan oleh Huda (2008) menyatakan bahwa di alam bawah sadar anak apapun tindakan kekerasan akan direkam dan dibawa hingga pada usia dewasa dan berlanjut terus sepanjang hidupnya. Penelitian yang dilakukan oleh Hidayati, Kaloeti \& Karyono (2011) mengatakan bahwa ayah ikut memberikan peran penting bagi perkembangan anak, pengalaman yang dilalui bersama sang ayah akan mempengaruhi seorang anak hingga dewasa nantinya. Dari penelitian tersebut didapatkan $8 \%$ cara yang digunakan ayah dalam menangani anak yang tidak patuh yaitu diberi hukuman fisik seperti cubitan, jeweran, dan pukulan serta diperoleh pula $21 \%$ dimarahi dengan kata - kata seperti anak nakal dan bandel.

YKAI/Yayasan Kesejahteraan Anak Indonesia menyatakan kekerasan dapat menimbulkan efek jangka panjang bagi anak di masa depan seperti cacat permanen, penurunan prestasi belajar, gangguan emosi bisa mengarah pada gangguan kepribadian, buruknya konsep diri anak, anak tidak aktif dan menarik diri dari lingkungan, berperilaku agresif, anak melakukan tindak kriminal seperti contohnya 
tawuran, pada masa dewasa nya anak menjadi penganiaya dan yang paling parah ialah menimbulkan kematian pada anak korban kekerasan tersebut.

Berdasarkan studi pendahuluan di SMP Negeri 22 Pekanbaru, dari 10 remaja 3 remaja perempuan dan 7 remaja laki-laki mendapat perilaku kekerasan ayah secara fisik dan verbal seperti dipukul, dicubit, diancam dan dibentak oleh sang ayah rata-rata siswa-siswi tersebut memiliki temperamen negative affectivity yang tinggi.

Berdasarkan latar belakang di atas, maka peneliti tertarik untuk mengetahui "Hubungan Perilaku Kekerasan Ayah terhadap Temperamen Remaja".

\section{METODE}

Penelitian ini menggunakan desain cross sectional dengan teknik stratified random sampling dan simple random sampling. Penelitian dilakukan di SMP Negeri 22 Pekanbaru dengan populasi 596 orang dan sampel 145 responden. Alat pengumpulan data menggunakan kuesioner. Uji statistik menggunakan uji chisquare.

\section{Hasil Penelitian}

\section{Analisa Univariat}

1. Karakteristik Responden

Berdasarkan tabel dibawah menunjukkan bahwa karakteristik responden yaitu, sebagian besar responden berjenis kelamin laki-laki sebanyak 77 orang $(53,1 \%)$, Usia responden sebagian besar yaitu 13 tahun sebanyak 61 orang $(42,1 \%)$. Usia ayah responden sebagian besar pada kelompok usia dewasa madya (36-45 tahun) sebanyak 87 orang $(60,0 \%)$. Pendidikan terakhir ayah paling banyak yaitu SMA sebanyak 71 orang (49,0\%). Pekerjaan ayah responden sebagian besar adalah wiraswasta sebanyak 79 orang $(54,5 \%)$. 
Tabel 1. Sebaran Karakteristik Remaja (N=145)

\begin{tabular}{clcc}
\hline No & \multicolumn{1}{c}{ Variabel } & $F$ & $\%$ \\
\hline 1 & Jenis kelamin & & \\
& a. Laki-laki & 77 & 53,1 \\
& b. Perempuan & 68 & 46,9 \\
\hline 2 & Usia & & \\
& a. 12 tahun & 46 & 31,7 \\
& b. 13 tahun & 51 & 42,1 \\
& c. 14 tahun & 35 & 24,1 \\
& d. 15 tahun & 3 & 2,1 \\
\hline 3 & Usia ayah & & \\
& a. Dewasa madya (36-45 tahun) & 87 & 60,0 \\
& b. Dewasa akhir (46-65 tahun) & 58 & 40,0 \\
\hline 4 & Pendidikan ayah & & \\
& a. SD & 11 & 7,6 \\
& b. SMP & 30 & 20,7 \\
& c. SMA & 71 & 49,0 \\
& d. Perguruan Tinggi & 33 & 22,8 \\
\hline 5 & Pekerjaan ayah & & \\
& a. PNS & 20 & 13,8 \\
& b. Swasta & 15 & 10,3 \\
& c. Wiraswasta & 79 & 54,5 \\
& d. Buruh & 15 & 10,3 \\
& e. Dll & 16 & 11,0 \\
\hline
\end{tabular}

Tabel 1.1 Distribusi Perilaku Kekerasan Ayah

\begin{tabular}{clcc}
\hline No & Perilaku kekerasan ayah & $f$ & $\%$ \\
\hline 1 & Tinggi & 78 & 53,8 \\
2 & Rendah & 67 & 46,2 \\
\hline & Jumlah & 145 & 100 \\
\hline
\end{tabular}

Berdasarkan tabel dibawah Perilaku kekerasan ayah sebagian besar tinggi sebanyak $78(53,8 \%)$.

\section{Bentuk perilaku kekerasan ayah}

Berdasarkan tabel dibawah menunjukkan bahwa bentuk perilaku kekerasan ayah, fisik yaitu mencubit 55 (37,9\%), memukul 83 (57,3\%), kekerasan verbal yaitu mengancam $41(27,9 \%)$ dan membentak $80(55,2 \%)$. 
Tabel 2. Bentuk Perilaku Kekerasan Ayah

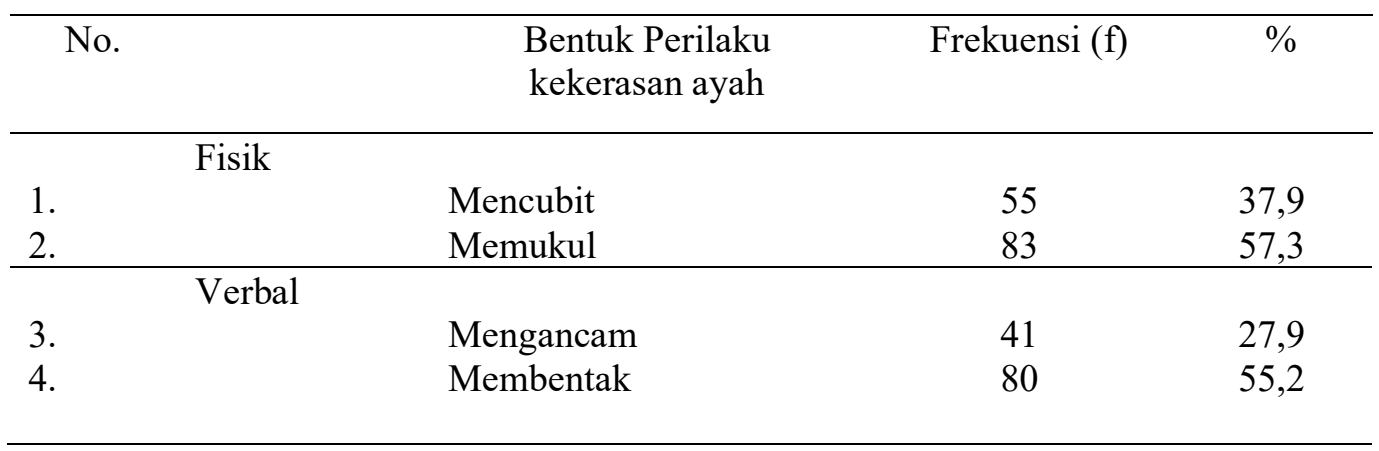

Tabel 3. Distribusi Frekuensi Temperamen Remaja

\begin{tabular}{llcccccc}
\hline No. & Temperamen & \multicolumn{3}{c}{ Kategori } & \multicolumn{3}{c}{ Total } \\
\cline { 2 - 7 } & remaja & Tinggi & $\%$ & Rendah & $\%$ & Jumlah & $\%$ \\
\hline $\mathbf{l}$ & $\begin{array}{l}\text { Temperamen } \\
\text { surgency }\end{array}$ & 79 & 54,5 & 66 & 45,5 & 145 & 100 \\
\hline $\mathbf{2}$ & $\begin{array}{l}\text { Temperamen } \\
\text { effortful control }\end{array}$ & 83 & 57,2 & 62 & 42,8 & 145 & 100 \\
\hline $\mathbf{3}$ & $\begin{array}{l}\text { Temperamen } \\
\text { negative } \\
\text { affectivity }\end{array}$ & 74 & 51,0 & 71 & 49,0 & 145 & 100 \\
\hline $\mathbf{4}$ & $\begin{array}{l}\text { Temperamen } \\
\text { affliativeness }\end{array}$ & 86 & 59,3 & 59 & 40,7 & 145 & 100 \\
\hline
\end{tabular}

Distribusi frekuensi responden berdasarkan temperamen remaja yaitu temperamen remaja surgentinggi sebanyak 79 responden (54,5\%), temperamen remaja effortful control tinggi sebanyak 83 responden $(57,2 \%)$, temperamen remaja negative affectivity tinggi sebanyak 74 responden $(51,0 \%)$ dan temperamen affiliativeness tinggi sebanyak 86 responden $(59,3 \%)$. 


\section{Analisa Bivariat}

1. Hubungan perilaku kekerasan ayah terhadap temperamen surgency

\begin{tabular}{cccccccc}
\hline $\begin{array}{c}\text { Perilaku } \\
\text { kekerasan } \\
\text { ayah }\end{array}$ & \multicolumn{3}{c}{$\begin{array}{c}\text { Temperamen surgency } \\
\text { remaja }\end{array}$} & & Total & $\mathbf{( \% )}$ & $\begin{array}{c}P \\
\text { value }\end{array}$ \\
\cline { 2 - 5 } & Tinggi & $(\%)$ & Rendah & $(\%)$ & & & \\
\hline Tinggi & 42 & 53,8 & 36 & 46,2 & 78 & 100 & 1000 \\
\hline Rendah & 37 & 55,2 & 30 & 44,8 & 67 & 100 & \\
\hline Total & 76 & 51,7 & 69 & 48,3 & 145 & 100 & \\
\hline
\end{tabular}

Uji chi-square didapatkan $P_{\text {value }}=1000$, hal ini menunjukkan tidak ada hubungan antara perilaku kekerasan ayah dengan temperamen surgency.

2. Hubungan perilaku kekerasan ayah terhadap temperamen effortful control

\begin{tabular}{|c|c|c|c|c|c|c|c|}
\hline \multirow{2}{*}{$\begin{array}{c}\text { Perilaku } \\
\text { kekerasan } \\
\text { ayah }\end{array}$} & \multicolumn{3}{|c|}{$\begin{array}{c}\text { Temperamen effortful } \\
\text { control remaja }\end{array}$} & \multirow[b]{2}{*}{$(\%)$} & \multirow[t]{2}{*}{ Total } & \multirow[t]{2}{*}{$(\%)$} & \multirow[t]{2}{*}{$\begin{array}{c}P \\
\text { value }\end{array}$} \\
\hline & Tinggi & $(\%)$ & Rendah & & & & \\
\hline Tinggi & 39 & 50,0 & 39 & 50,0 & 78 & 100 & 0,083 \\
\hline Rendah & 44 & 65,7 & 23 & 34,3 & 67 & 100 & \\
\hline Total & 83 & 52,4 & 62 & 47,6 & 145 & 100 & \\
\hline
\end{tabular}

Uji chi-square didapatkan $P_{\text {value }}=0.083$, hal ini menunjukkan tidak ada hubungan antara perilaku kekerasan ayah dengan temperamen effortful control. 3. Hubungan perilaku kekerasan ayah terhadap temperamen negative affectivity

\begin{tabular}{cccccccc}
\hline $\begin{array}{c}\text { Perilakul } \\
\text { kekerasanl } \\
\text { ayah }\end{array}$ & \multicolumn{2}{c}{$\begin{array}{c}\text { Temperamen negative } \\
\text { affectivity remaja }\end{array}$} & & Total & $(\%)$ & $\begin{array}{c}P \\
\text { value }\end{array}$ \\
\cline { 2 - 6 } & Tinggi & $(\%)$ & Rendah & & & & \\
\hline Tinggi & 43 & 55,1 & 35 & 44,9 & 78 & 100 & 0,370 \\
\hline Rendah & 31 & 46,3 & 36 & 53,7 & 67 & 100 & \\
\hline Total & 74 & 51,0 & 71 & 49,0 & 145 & 100 & \\
\hline
\end{tabular}


Uji chi-square didapatkan $P_{\text {value }}=0.370$, hal ini menunjukkan tidak terdapat hubungan antara perilaku kekerasan ayah dengan temperamen negative affectivity. 4. Hubungan perilaku kekerasan ayah terhadap temperamen affiliativeness

\begin{tabular}{|c|c|c|c|c|c|c|c|}
\hline \multirow{2}{*}{$\begin{array}{c}\text { Perilaku } \\
\text { kekerasan } \\
\text { ayah }\end{array}$} & \multicolumn{3}{|c|}{$\begin{array}{c}\text { Temperamen } \\
\text { affiliativeness remaja }\end{array}$} & \multirow[b]{2}{*}{$(\%)$} & \multirow[t]{2}{*}{ Total } & \multirow[t]{2}{*}{$(\%)$} & \multirow[t]{2}{*}{$\begin{array}{c}P \\
\text { value }\end{array}$} \\
\hline & Tinggi & $(\%)$ & Rendah & & & & \\
\hline Tinggi & 44 & 56,4 & 34 & 43,6 & 78 & 100 & 0,550 \\
\hline Rendah & 42 & 62,7 & 25 & 37,3 & 67 & 100 & \\
\hline Total & 86 & 59,3 & 59 & 40,7 & 145 & 100 & \\
\hline
\end{tabular}

Uji chi-square didapatkan $P_{\text {value }}=0.550$, hal ini menunjukkan tidak ada hubungan antara perilaku kekerasan ayah dengan temperamen affiliativeness.

\section{PEMBAHASAN}

\section{Karakteristik Responden}

Hasil penelitian menunjukkan sebagian besar remaja laki-laki sebanyak 77 responden (53,1\%). Menurut Tandry (2017) anak laki-laki mempunyai kemarahan yang lebih besar dibandingkan dengan anak perempuan. Pada SMPN 22 Pekanbaru siswa terbanyak yaitu berjenis kelamin laki-laki. Survei kekerasan terhadap anak Indonesia (2013) menunjukkan bahwa kekerasan yang dilakukan oleh ayah cenderung ditujukan kepada anak laki-laki sebanyak 41,1\% yang mendapat perilaku kekerasan fisik dari ayah dan sebanyak 35,6\% mereka mendapat kekerasan emosional dari ayah.

Laki-laki memiliki kecenderungan lebih besar dibandingkan perempuan untuk memperlihatkan kemarahannya dan melampiaskannya ke arah tindakan agresif khususnya ketika budaya dan lingkungan membenarkan hal tersebut (Santrock, 2007).

Berdasarkan hasil penelitian menunjukkan bahwa sebagian besar responden berusia 13 tahun sebanyak 61 orang (42,1\%). Menurut Ali \& Asrori (2017) tugas perkembangan remaja difokuskan pada usaha untuk meninggalkan perilaku dan sikap kekanak-kanakan dan upaya untuk mencapai kemampuan berperilaku dan 
bersikap dewasa. Pada masa ini remaja berusaha untuk mencapai kemandirian emosional, memahami dan menghayati nilai-nilai yang ditanamkan oleh orang tua, dan mampu membina pergaulan yang sehat dengan teman sebaya.

Hal ini berkaitan dengan temperamen surgency yaitu remaja dengan temperamen surgency tinggi memiliki sifat suka memasuki lingkungan baru dan menyukai tantangan. Pada masa ini juga peningkatan emosional terjadi secara cepat hal ini merupakan hasil perubahan fisik terutama hormon yang terjadi pada masa remaja. remaja dituntut untuk lebih mandiri dan bertanggung jawab atas perbuatan dan tingkah lakunya (Jahja, 2011).

Berdasarkan hasil penelitian menunjukkan sebagian besar ayah berusia Dewasa madya (36-45 tahun) yaitu sebanyak 87 orang (60,0\%). Menurut Jahja (2011) masa dewasa madya dianggap sebagai usia yang berbahaya dalam rentang kehidupan, terutama dari kalangan pria yang ingin melakukan pelampiasan untuk kekerasan yang berakhir sebelum memasuki usia lanjut.

Hasil penelitian didapatkan perilaku kekerasan yang dilakukan ayah yang berusia dewasa madya yaitu tinggi. kekerasan tersebut dilakukan ayah pada remaja dalam bentuk mencubit, memukul, mengancam dan membentak sebanyak $51,7 \%$. Ketika memasuki usia dewasa madya terjadi perubahan emosional. Kebanyakan individu biasanya sudah mampu berpikir jernih, lebih tenang, stabil, dan mampu menghadapi berbagai perubahan yang terjadi dilingkungannya. Hal ini merupakan salah satu kestabilan dan kematangan emosi. Namun bagi dewasa madya yang memiliki kepribadian yang belum matang, mereka masih menitikberatkan emosi dari pada pikiran. Mereka masih berperilaku tempramental yang tinggi, mudah marah, tidak sabaran, penuh kebencian, masih senang berkelahi dan asal-asalan baik dalam berpkir maupun bertindak (Pieter, 2017).

Berdasarkan penelitian menunjukkan sebagian besar ayah pendidikan terakhirnya yaitu SMA sebanyak 71 orang (49,0\%). Hasil penelitian Halawa (2014) juga menjelaskan bahwa dari 20 responden sebagian besar responden berpendidikan terakhir SMA sebanyak 11 orang (55\%). Penelitian Puspitawati, Djamaludin \& Nusanti (2011) didapatkan kekerasan pada anak akan menurun jika ayah memiliki pendidikan tinggi. 
Namun hasil penelitian di SMPN 22 Pekanbaru menunjukan sebagian besar ayah berpendidikan menengah $48,0 \%$ dan tinggi $22,8 \%$ hal ini terlihat bahwa perilaku kekerasan tidak hanya terjadi akibat rendah nya tingkat pendidikan individu. Faktor lain yang dapat mempengaruhi perilaku kekerasan ialah kepribadian orang tua yang keras dan sebagian orang tua masih menganggap kekerasan dalam mendidik anak merupakan sebuah kewajaran karena telah dilakukan turun temurun (Beranda Agency, 2015).

Berdasarkan hasil penelitian menunjukkan bahwa sebagian besar ayah responden bekerja sebagai wiraswasta sebanyak 79 orang $(54,5 \%)$. Sedangkan penelitian Harianti dan Siregar (2014) didapatkan 52\% pekerjaan responden adalah petani dan $28 \%$ responden bekerja dibidang wiraswasta.

Status ekonomi sangat berpengaruh pada perkembangan hubungan orang tua dengan anak. Penelitian yang dilakukan Nugroho Akbar (2009) menyebutkan bahwa income yang diperoleh orangtua berpengaruh terhadap tingkat pengasuhan orang tua. Orang tua dengan penghasilan rendah cenderung memiliki perilaku kekerasan yang lebih tinggi dibandingkan dengan orangtua yang memiliki penghasilan tinggi. Ketika mengalami kesulitan ekonomi, orangtua menjadi mudah marah dan frustasi, serta tekanan psikologis mereka akan menurunkan kemampuan pengasuhan yang akan berpengaruh pada kekerasan (Stuart \& Sundeen, 2006).

\section{Analisa Bivariat}

1. Hubungan Perilaku Kekerasan Ayah Terhadap Temperamen Surgency

Berdasarkan hasil uji chi square yang dilakukan, didapat $p_{\text {value }}=1000$ lebih besar dari $\alpha=0,05$ yang berarti $\mathrm{H}_{0}$ diterima. Hal ini berarti tidak ada hubungan antara perilaku kekerasan ayah dengan temperamen surgency remaja.

Hal ini dapat dipahami bahwa perilaku kekerasan ayah bukanlah satusatunya yang mempengaruhi temperamen. Hal ini mungkin dipengaruhi oleh faktor dari dalam diri remaja maupun dari lingkungan. Menurut Santrock (2011) meskipun relatif stabil sepanjang hidup, temperamen dapat berubah dan berkembang bersamaan dengan pengalaman yang dialami individu serta 
kedewasaan. Salah satu faktor yang mempengaruhi temperamen ialah pengaruh biologis dan keturunan.

Remaja dengan temperamen surgency, suka memasuki lingkungan yang baru. Sedangkan dampak dari perilaku kekerasan diantaranya ialah pasif, menarik diri dari lingkungan, memiliki konsep diri yang buruk dan takut serta tidak mampu berhubungan dengan orang baru (YKAI dalam Huraerah, 2012). Sehingga terlihat meskipun remaja terpapar perilaku kekerasan ayah yang tinggi namun remaja tetap memiliki temperamen yang baik. Hal ini didukung oleh interaksi ibu dan remaja yang baik sehingga anak tidak terkena dampak buruk dari tindak kekerasan tersebut.

2. Hubungan Perilaku Kekerasan Ayah Terhadap Temperamen Effortful control

Berdasarkan hasil uji chi square yang dilakukan, didapat $p_{\text {value }}=0,083$ lebih besar dari $\alpha=0,05$ yang berarti $\mathrm{H}_{0}$ diterima. Hal ini berarti tidak ada hubungan antara perilaku kekerasan ayah dengan temperamen effortful control remaja.

Dimensi effortful control mengarah pada kemampuan untuk mengontrol suatu emosi. Remaja yang mempunyai kendali emosi yang tinggi biasanya menunjukkan bakat untuk menyembunyikan hasrat yang bergejolak agar tidak terlihat dan remaja biasanya mempunyai cara - cara khusus untuk menenangkan diri mereka. Sebaliknya, remaja yang mempunyai kendali emosi yang rendah sering kali tidak bisa mengendalikan hasrat yang bergejolak sehingga remaja akan terlihat gampang gelisah dan memiliki emosi yang tinggi (Eisenberg, dkk dalam Santrok, 2007).

Anak yang didukung dengan kondisi lingkungan yang baik akan memiliki kontrol emosi yang baik. Jika anak mampu mengenal temperamen yang dimiliki dirinya sendiri maka mereka akan mampu mengendalikan dan mengarahkan perilaku nya sendiri dengan baik ke arah yang positif.

3. Hubungan Perilaku Kekerasan Ayah Terhadap Temperamen Negative affectivity

Berdasarkan hasil uji chi square yang dilakukan, didapat $p_{\text {value }}=0,370$ lebih besar dari $\alpha=0,05$ yang berarti $\mathrm{H}_{0}$ diterima. Hal ini berarti tidak ada 
hubungan antara perilaku kekerasan ayah dengan temperamen negative affectivity remaja.

Menurut Ellis dan Rothbart (1999), dimensi negative affectivity mengarah pada kemudahan mengalami stress. Remaja dengan temperamen ini memiliki emosi yang tidak stabil, agresif, mudah frustasi, mudah marah dan mudah menangis. Semakin tinggi perilaku kekerasan ayah maka semakin tinggi temperamen negative affectivity pada remaja. Namun hasil penelitian di SMPN 22 Pekanbaru didapatkan tidak terdapat hubungan perilaku kekerasan ayah dengan temperamen negative affectivity tinggi.

Hal ini disebabkan karena meskipun responden memiliki temperamen negative affectivity tinggi namun remaja juga memiliki temperamen effortful control yang tinggi. Dimana temperamen effortful control yang tinggi ini memperlihatkan kemampuan remaja untuk mengendalikan emosi, dengan adanya temperamen effortful control tersebut remaja mempunyai cara-cara khusus untuk menenangkan diri mereka sehingga remaja mampu mengendalikan sifat-sifat negatif dari temperamen negative affectivity tinggi tersebut.

4. Hubungan Perilaku Kekerasan Ayah Terhadap Temperamen Affiliativeness

Berdasarkan hasil uji chi square yang dilakukan, didapat $p_{\text {value }}=0,550$ lebih besar dari $\alpha=0,05$ yang berarti $\mathrm{H}_{0}$ diterima. Hal ini berarti tidak ada hubungan antara perilaku kekerasan ayah dengan temperamen affiliativeness remaja.

Menurut Ellis dan Rothbart (1999), dimensi affiliativeness mengarah pada keinginan akan kehangatan dan kedekatan dengan orang lain. Remaja dengan temperamen ini memiliki kepribadian yang terbuka, menyadari perubahan-perubahan kecil yang terjadi di lingkungannya, hangat, dan rela berkorban untuk orang yang disayangi.

Salah satu yang mempengaruhi temperamen remaja yaitu teman sebaya. Remaja memiliki kebutuhan untuk disukai dan diterima teman sebaya. Remaja akan merasa senang apabila diterima dan sebaliknya jika remaja ditolak dan diremehkan remaja akan merasa tertekan dan cemas (Santrock, 2007). 
Pada SMPN 22 Pekanbaru terlihat remaja menjalin hubungan yang baik dengan teman sebaya, sehingga remaja merasa diterima dilingkungannya meskipun dilingkungan rumah remaja mendapat perilaku kekerasan ayah, hal tersebut dipengaruhi oleh dukungan teman sebaya dan persahabatan yang dijalin oleh remaja.

\section{Kesimpulan}

Hasil penelitian yang telah dilakukan tentang Hubungan Perilaku kekerasan ayah dengan Temperamen Remaja menunjukkan tidak terdapat hubungan yang signifikan antara perilaku kekerasan ayah dengan temperamen remaja dengan nilai p-value surgency $=1000, p$-value effortful control $=0,083$, p-value negative affectivity $=0,370$ dan $\mathrm{p}$-value affiliativeness $=0,550>(\alpha 0,05)$. 


\section{Rujukan}

Agency, B. (2015). Mengasuh dan mendidik buah hati tanpa kekerasan. Jakarta: PT Elex Media Komputindo

Aisyah, S. (2015). Perkembangan peserta didik dan bimbingan belajar. Yogyakarta: Deepublish

Ali, M. \& Ansori, M. (2017). Psikologi perkembangan remaja perkembangan peserta didik. Jakarta: PT Bumi Aksara

Fudyartanta, K. (2012). Psikologi perkembangan. Yogyakarta : Pustaka Pelajar

Halawa, A. (2014). Hubungan Pengetahuan Keluarga Tentang Kekerasan Pada Anak Dengan Tindakan Prilaku Kekerasan Pada Anak. Surabaya. http://download.portalgaruda.org/

Harianti, E. \& Siregar S. S. (2014). Faktor-faktor penyebab kekerasan orang tua terhadap anak. Jurnal pemerintahan dan sosial politik 2 (1). Medan. http://ojs.uma.ac.id/

Hidayati, F., Kaloeti, D. V. S., \& Karyono. (2011). Peran ayah dalam pengasuhan anak. Jurnal Psikologi Undip Vol. 9 No. 1. https://ejournal.undip.ac.id/

Huda, N. (2008). Kekerasan terhadap anak dan masalah sosial yang kronis. Jurnal pena justisia volume VII No. 14, tahun 2008. http://www.unikal.ac.id/

Huraerah, A. (2012). Kekerasan terhadap anak. Bandung : Nuansa Cendekia

IDAI. (2013). Masalah kesehatan mental emosional remaja. http://www.idai.or.id/ Jahja, Y. (2011). Psikologi perkembangan edisi pertama. Jakarta: Prenadamedia Group

Perdani, F. L. \& Yusuf, H. (2013). Faktor potensi kekerasan orangtua terhadap anak: Studi kasus di Kelurahan Cibeber, Kecamatan Cimahi Selatan Kota Cimahi. Jurnal ilmu kesejahteraan sosial Vol. 12 No. 2. https://jurnal.usu.ac.id/

Pieter, H. Z. (2017). Dasar-dasar komunikasi bagi perawat. Jakarta: Kencana

Putnam, S. P., Ellis L. K. \& Rothbart, M. K. (2001). Early Adolescent Temperament Questionnaire-Revised. https://research.bowdoin.edu/rothbart-temperamentquestionnaires/request-forms/downloads/ 
Ramadhianti, N. \& Alfiasari (2017). Temperamen, interaksi ibu-remaja dan kecerdasan emosi remaja pada keluarga dengan ibu bekerja di perdesaan. Jurnal ilmu keluarga dan konsumen. Vol 10, 2017. Bogor. http://www.journal.ipb.ac.id/ Rezky, B. (2010). Be a smart parent, cara hebat mengasuh anak ala supernanny. Yogyakarta: Jogja Bangkit Publisher

Santrock, J. W. (2007). Perkembangan anak. Jakarta: Erlangga . (2007). Remaja edisi kesebelas jilid 1. Jakarta: Erlangga . (2007). Remaja edisi kesebelas jilid 2. Jakarta: Erlangga

Willis, S. S. (2012). Remaja \& masalahnya. Mengupas berbagai bentuk kenakalan remaja, narkoba, free sex dan pemecahannya. Bandung: Alfabeta 